\title{
The Phenomenon of Company Towns: Specific Features of Their Genesis and Development
}

\author{
M.A. Ulyanychev \\ Peoples' Friendship University of Russia (RUDN University) \\ Miklukho-Maklaya str., 6, Moscow, Russian Federation, 117198
}

\begin{abstract}
The article analyzes the social phenomenon of single-industry towns (company towns), their role in the modern market economy, their genesis in Russia and other countries. The author observes historical stages of development of single-industry towns in Russia, as well as the features of their occurrence in the Soviet Union in connection with city-forming enterprises, which in addition to economic activities performed social functions. The characteristics of the development of single-industry towns in Europe, North America and are being compared. Distinctive features of the industrial enterprises of the cities formed in the Soviet Union are allocated. The article analyzes the problems of functioning and development of single-industry towns, examines foreign and domestic strategies for the rehabilitation of single-industry municipalities, including current measures to support such towns in the Russian Federation.
\end{abstract}

Keywords: single-industry towns, company towns, social development, urban development, management of social processes, state support of single-industry towns

\section{Introduction}

Company towns are the "inheritors" of the industrial era, which is reflected in their impact on the social and economic development of territories. Some experts believe that the creation of single-industry towns is a necessary element of economic development. Others suppose that single-industry towns don't meet the requirements of the modern market economy. They cannot meet the market's demand for new technologies, goods and services and that can harm the economy and social development of the country and its regions $[1 ; 2 ; 3 ; 4 ; 5]$.

The problems of single-industry towns are the focus of research in various scientific disciplines e.g. sociology, economics, urban studies, statistics and many others. They explore the economic activities of the company towns, its territorial organization and demography of the area. The study of the structural components of the social and economic system of company towns show their close relationship and mutual dependence. Therefore, it seems that a systematic approach is a 
methodological tool that allows a comprehensive study of the company town phenomenon. The essence of this approach is that the system is considered from the point of studying the internal relations of the elements with each other and external relations with the environment (including the historical aspect), as well as establishing causal relationships between the elements and their capability for organization and development.

The system analysis of a single-industry town is based on the principle of structural functionalism underlying the understanding of a company town as a system. This principle helps to consider the functional specialization of individual elements of the urban system, and their role in the integrity of the joint object. Thus, from the point of view of the system approach a company town as a social phenomenon is a complex of elements, as well as subsystems consisting of them, located within a limited area, where the overall integrity shows misbalance of its subsystems and elements.

A great example of "imbalance" of structural elements of the company town system is the industrial complex of Detroit in the United States. The city and its main enterprises fell into decay because of the energy crisis of the 70s. Companies' owners had to bring production to other cities and even countries, as the development of business in this area turned to be not feasible economically. The population of Detroit lost stability, work, housing, wealthy residents left the city [6]. Mass media wrote that because of lack of economic stability and social institutions, the remaining inhabitants "quickly became illiterate and their level of social consciousness quickly decreased" [7].

Such processes should serve as a special signal for Russia, where city-forming enterprises are a significant part of the economy, and the population of singleindustry towns is about $10 \%$ of the total population of the country. In this regard, it is necessary to analyze the genesis of single-industry towns, the causes of their formation, development and decline, as well as their specific problems.

\section{Results}

The rise of single-industry towns is associated with the entry of most countries in the world into the era of industrial society. Thus, the emergence of such towns in the US is associated with the development of industry in the North-East (Pittsburgh, Detroit), the creation of a large agricultural and industrial cluster in the West and the industrial agglomeration in the South, including such States as New Mexico, California and Texas. Single-industry towns in these areas have long been the drivers of the US economy. Canadian experience in the development of the Northern territories is associated with the emergence of single-industry towns in the provinces of Quebec, Ontario and Alberta. The program of development of the Northern territories took into account the potential unprofitability of these places without state support, which resulted in a major project for the creation, development and support of highly specialized cities, which involved only highqualified specialists, as well as created research centers to study the potential of the developed territories. A striking example of a single-profile territory is also the 
Ruhr valley in Germany. A distinctive feature of the Ruhr was the mass opening of universities to increase the potential for the development of obsolete enterprises. Later, the integration of science and production in the Ruhr valley grew into the opening of technology parks, which became the basis of economic and social prosperity of the region.

The genesis of single-industry towns in Russia deserves special attention. It should be noted that the development of such settlements took place in several historical stages. The first appearance of single-profile territories is associated with the creation of manufactories under tzar Peter the Great. At this time, the first factories-settlements began to be formed, which later developed into large industrial centers, such as Tula, Chelyabinsk, etc. The second stage is connected with the mass development of light industry, including the appearance of industries aimed at the development of "village crafts" in Gavrilov-Yam, Gus-Khrustalny, Gzhel. At the same time, the first mining settlements along the Trans-Siberian railway began to form. During Stalin's industrialization lots of single-industry towns appeared, having one or two industrial enterprises. Such cities include Magnitogorsk, Novokuznetsk, Vorkuta. A significant number of single-industry towns was formed during the war years after the evacuation of large enterprises from Central Russia. Post-war years are marked by a sharp increase in the number of closed singleindustry towns. These include cities with the presence of enterprises of the militaryindustrial sector, nuclear industry and strategic military units.

At the same time, the development of the so-called science towns - singleindustry towns based on research institutes. The first Russian science city was the Akademgorodok in Novosibirsk, followed by Zelenograd, Troitsk, Dubna and others. Scientific and production facilities of such cities produce high-tech products in demand on the international market.

A distinctive feature of single-industry towns in the Soviet Union was a close connection of these settlements with the city-forming enterprises, which implemented not only economic but also social functions. Enterprises provided workers with corporate housing, owned the departments of public utilities, health care and education, which increased the total cost of the product. This became a problem after the transition of the Russian economy to a market basis as the products of the city-forming enterprises became uncompetitive due to inflated prices. Such processes became the first problem of city-forming enterprises in the Russian Federation, which could not but lead to the rise of social and economic problems in the single-industry towns.

In the practice of the genesis of single-industry towns we can identify the main problems that are peculiar for these areas. First, there is an acute question of maintaining the dependence of single-industry towns on the city-forming enterprises, whose production is not ready to meet the needs of the market, which entails reduction of jobs, increase in unemployment, deterioration of social and economic conditions for the working population of a single-industry town. Dependence on city-forming enterprise also affects the backwardness and gradual obsolescence of the infrastructure of single-industry towns in the absence of support from the enterprise, which was a source of development of the territory in the conditions of the planned economy. 
The second obvious problem of single-industry towns is the outflow of population to larger and more diversified cities. This is primarily due to the outflow of young personnel, who, not seeing the potential of employment in outdated cityforming enterprises, leave to apply their knowledge and skills in potentially more promising cities and regions. In this regard, there is a growing shortage of qualified personnel capable of both introducing innovative technologies in production and developing new ones considering regional peculiarities. The aging population of single-industry towns is often not able to fully meet the needs of modern development trends, pushing innovation, resisting attempts to diversify production. This problem largely hinders the economic development of single-industry towns.

This is proved by many company towns in Russia, where in contemporary realities it is necessary to take urgent measures for the rehabilitation of depressed single-industry municipalities. Two strategies can be applied as a solution to the problems mentioned above. The first, American, model provides the resettlement of non-working population of single-industry towns to those areas where there is a possibility of employment. Such model concerns the preservation of the town's functions, despite a significant decrease in size. The second strategy is European. It provides the integration of public and private programs for the development of territories and diversification of production of city-forming enterprises. These programs include the development of infrastructure of single-industry towns, the improvement of the environmental situation, re-educating of the unemployed population new professions, as well as support for small and medium-sized businesses.

\section{Conclusion}

The logical solution to the "problem of single-industry towns" in Russia is a large-scale state program to support local initiatives in company towns, as well as support for innovative projects to reload outdated city-forming enterprises for new production that meet market requirements.

It should be noted that the first steps in this direction are already being taken. Thus, within the framework of the program of support for single-industry municipalities, a set of measures for the social and economic development of this towns are being implemented. The first of these measures is the creation of the socalled territories of advanced social and economic development, which involve the use of a special legal regime of business activity throughout the company town, including preferential taxation, reduced rates of social fees, a simplified procedure for monitoring and supervision.

The second direction of state support is the creation of a mechanism to support investment projects implemented in the territory of single-industry towns based on project financing, which contributes to increase of lending to industrial enterprises on long-term and preferential terms. In this regard, support and assistance in the preparation and participation in the implementation of new investment projects in single-industry towns is also relevant. It is supposed to increase the investment attractiveness, attract qualified personnel and solve the problem of unemployment in single-industry towns. 
At the present stage, more than 300 municipalities meet the criteria of a single-profile settlement in the Russian Federation [8], which causes high priorities in the implementation of support programs. Stable social and economic development of single-industry towns will depend on their effective application. It should also be taken in mind that any program can be considered successful only if all measures are taken to prevent economic and social crisis in single-industry towns, as well as the ability to overcome this crisis. In this case, single-industry towns will be able to provide financial stability for local residents, guarantee a stable growth of the economic potential of local enterprises, as well as become competitive players in both domestic and international markets.

\title{
REFERENCES
}

[1] Ioffe G.V. Multi-structure Shift. Provincial Business Magazine. 2009; 10.

[2] Lyubovny V.Ya. Monoprofilnye goroda v usloviyah krizisa: sostoyanie, problemy, vozmozhnosti reabilitatsii [Single-industry Town in Crisis: Status, Challenges, Opportunities of Rehabilitation]. Moscow: ZAO «Dontransprint»; 2009. 110 p. (In Russ.).

[3] Smorchkov V.I., Silvestrov S.N. Razvitie monogorodov v Rossii [The Development of Single-industry Towns of Russia]. Moscow: Financial University; 2013. 168 p. (In Russ.).

[4] Vlasova N.D. Animitsa E.G. Problemy i perspektivy razvitija monogorodov v Rossii [Problems and Prospects of Development of Single-industry Towns of Russia]. Ekaterinburg: Publishing House of Ural State Economic University; 2009: 28-29 (In Russ.).

[5] Zhikharevich B.S. Universitet kak faktor lokal'nogo jekonomicheskogo razvitija [University as a Factor of Local Economic Development]. Education in the System of Social Coordinates. 2014; 3: 42-46 (In Russ.).

[6] Johnson R. Graphic: Detroit Then and Now. Nationalpost.com. 01.02.2013. URL: nationalpost.com/news/graphics/graphic-detroit-then-and-now. Accessed: 28.04.2019.

[7] Detroit Is "Most Dangerous City in America" for Fourth Year in a Row, Forbes Report Says. CBS News. 22.10.2012. URL: cbsnews.com/news/detroit-is-most-dangerouscity-in-america-for-fourth-year-in-a-row-forbes-report-says/. Accessed: 28.04.2019.

[8] Resolution of the Government of the RF of July 29, 2014 No 709 "On the criteria for classifying municipalities as single-industry towns and categories of single-industry towns depending on the risks of deterioration of their socio-economic situation". Assembly of legislation of the RF; 04.08.2014; No 31: 4425 (In Russ.).

Научная статья

\section{Феномен корпоративных городов: специфические особенности генезиса и развития}

\author{
М.А. Ульянычев \\ Российский университет дружбы народов \\ ул. Миклухо-Маклая, 6, Москва, Россия, 117198
}

Аннотация. В статье анализируется социальный феномен моногородов (корпоративных городов), их роль в современной рыночной экономике, их генезис в России и других странах. Автор рассматривает исторические этапы развития моногородов в России, а также особенности их возникновения в Советском Союзе в связи с 
градообразующими предприятиями, которые помимо хозяйственной деятельности выполняли социальные функции. В статье сравниваются особенности развития моногородов в Европе, Северной Америке и других странах. Выделены отличительные особенности промышленных предприятий моногородов, образовавшихся в СССР. В статье анализируются проблемы функционирования и развития моногородов, рассматриваются зарубежные и отечественные стратегии реабилитации моногородов, в том числе современные меры поддержки таких городов в Российской Федерации.

Ключевые слова: моногорода, корпоративные города, социальное развитие, градостроительство, управление социальными процессами, государственная поддержка моногородов

\section{Информация об авторе:}

Ульянычев Максим Александрович - аспирант кафедры социологии Российского университета дружбы народов (ORCID ID: 0000-0003-0642-8094) (e-mail: maksim.ulyanychev@mail.ru).

\section{Information about the author:}

Maxim A. Ulyanychev - PhD Student of the Department of Sociology, Peoples' Friendship University of Russia (RUDN University) (Russian Federation) (ORCID ID: 0000-00030642-8094) (e-mail: maksim.ulyanychev@ mail.ru).

\section{Для цитирования:}

Ulyanychev M.A. The Phenomenon of Company Towns: Specific Features of Their Genesis and Development // Вестник Российского университета дружбы народов. Серия: Государственное и муниципальное управление. 2020. Т. 7. № 2. С. 118-123. DOI: $10.22363 / 2312-8313-2020-7-2-118-123$

\section{For citation:}

Ulyanychev M.A. The Phenomenon of Company Towns: Specific Features of Their Genesis and Development. RUDN Journal of Public Administration. 2020; 7 (2): 118-123. DOI: $10.22363 / 2312-8313-2020-7-2-118-123$ 